\title{
PLANT DIVERSITY OF THE MID SILURIAN (LOWER WENLOCK, SHEINWOODIAN) TERRESTRIAL VEGETATION PRESERVED IN MARINE SEDIMENTS FROM THE BARRANDIAN AREA, THE CZECH REPUBLIC
}

\author{
MILAN LIBERTÍN ${ }^{1}$, JIŘí KVAČEK ${ }^{1, *}$, JIŘÍ BEK², PETR ŠTORCH² \\ ${ }^{1}$ Department of Palaeontology, National Museum, Prague, Václavské náměstí 68, 11000 Prague 1, the Czech Republic; \\ e-mail: milan_libertin@nm.cz, jiri_kvacek@nm.cz. \\ ${ }^{2}$ Institute of Geology of the Czech Academy of Sciences, v.v.i., Rozvojová 269, 16500 Prague 6, the Czech Republic; \\ e-mail: bek@gli.cas.cz, storch@gli.cas.cz. \\ * corresponding author
}

Libertín, M., Kvaček, J., Bek, J., Štorch, P. (2018): Plant diversity of the mid Silurian (lower Wenlock, Sheinwoodian) terrestrial vegetation preserved in marine sediments from the Barrandian area, the Czech Republic. - Fossil Imprint, 74(3-4): 327-333, Praha. ISSN 2533-4050 (print), ISSN 2533-4069 (on-line).

\begin{abstract}
Plant mega- and microfossils are described from the middle Sheinwoodian of the Barrandian area. The material comes from the Loděnice locality and the same horizon as the earliest unequivocal land plant, Cooksonia barrandei LIBERTín, J.KvaČEK, BeK, ŽÁrskÝ et ŠTorch. Its age (432 Myr) is inferred from the associated graptolite fauna, including the zonal index graptolite Monograptus belophorus. Megafossils have clear similarity with Cooksonia, due to their dichotomised axes with slightly widened subtending axes bearing putative sporangia. They document some of the plant diversity that was in place when the first proven representative of the genus Cooksonia appeared, and together with dispersed spores they provide strong and important evidence that a diversified terrestrial ecosystem had developed on the Barrandian volcanic archipelago in the peri-Gondwanan realm by the end of the Sheinwoodian Stage of the Silurian Period.
\end{abstract}

Kew words: Cooksonia, Barrandian, Silurian, Wenlock, early land plants

Received: November 6, 2018 | Accepted: Novemebr 26, 2018 | Published: December 28, 2018

\section{Introduction}

Early land plants found in the Silurian marine sediments of the Barrandian area of central Bohemia (the Czech Republic) have been a recent focus of Czech palaeobotanists (Kraft and Kvaček 2017, Kraft et al. 2018, Libertín et al. 2018). The latter publication is of particular importance because it documents Cooksonia barrandei LIBERTín, J.KVAČEK, BEK, ŽÁrSKÝ et ŠTORCH in sediments dated to about $432 \mathrm{Myr}$, making it the earliest megafossil polysporangiate land plant (Libertín et al. 2018). It is of particular interest that the next oldest evidence of polysporangiate land plants comes from sediments approximately 5 Myr younger (Homerian Stage) in Ireland (Edwards et al. 1983). Most of the early land plants are referred to as cooksonioids (e.g. Taylor et al. 2009), and they are characterized by very small size. This particular feature led Boyce (2008) to hypothesize that their life cycle was similar to that of modern bryophytes, however this was questioned by Libertín et al. (2018), who used large size of $C$. barrandei as one of the major counter-arguments.

Here we document dichotomizing plant fossil remains some of which have putative sporangia attached. The fossils come from the same locality as $C$. barrandei, Loděnice in the Barrandian area of the Czech Republic (Text-fig. 1a, b), and they provide evidence of additional plant diversity at a very early stage of vascular plant evolution.

\section{Material and methods}

The fossils consist of the type material of Cooksonia barrandei and three more fertile specimens from the Loděnice locality. The most important specimens come from the historical collection of Joachim Barrande (1799 - 1883) who identified them as marine algae (Fucoides) in accordance with understanding of the material at the time and thus seemingly uninteresting. The material was re-discovered in 2012 by Vojtěch Turek of the National Museum, Prague, while moving the collection to the museum's new repository building. The best-preserved specimens, very probably fertile cooksonioid plants, are described here, and they bear characters that distinguish them from $C$. barrandei. In several cases fragments of Cooksonia were found on the same bedding plane as the 

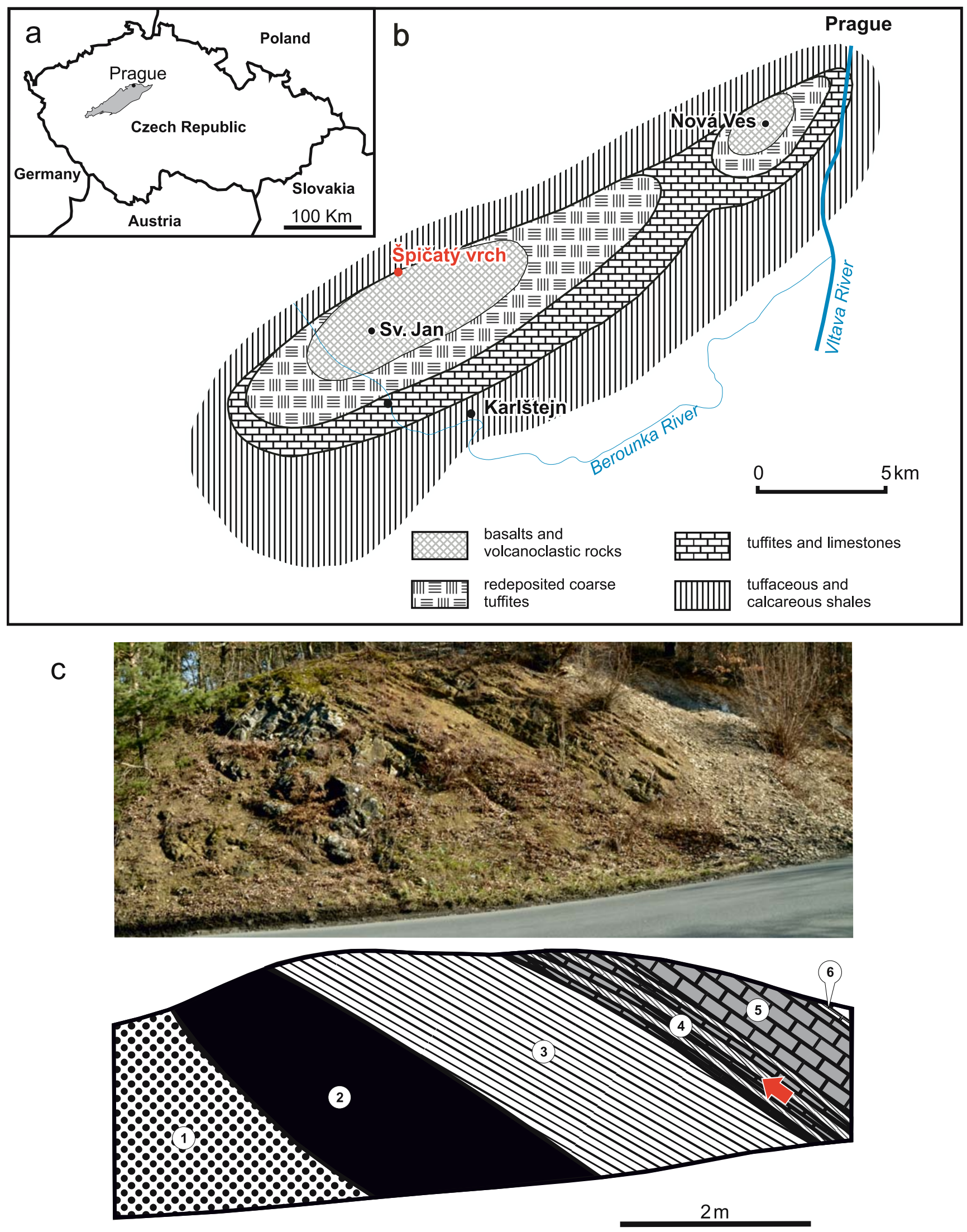

graptolite Monograptus belophorus (MENEGHINI) $=$ M. flexilis ELLES. This fact, together with similarities in lithology and associated trilobite and shell-bearing fauna occurring on the bedding plane of the samples in this rediscovered box, led us to infer that the approximately 50 cooksonioid specimens, including the type material of $C$. barrandei, came from the Monograptus belophorus Biozone.

We relocated the original locality where Barrande collected the specimens of $C$. barrandei and all the present material we examined here including three other fertile 
specimens. Eleven sterile fragments of cooksonioids have been newly collected from the brown-grey calcareous and tuffaceous shale of the belophorus Biozone of the Motol Formation that is exposed near to Barrande's original locality (Text-fig. 1b). However, none of them is as completely preserved as the historical specimens.

The layer with Cooksonia fossils contains a diverse marine fauna. Besides Monograptus belophorus, other stratigraphically important graptolites, including Monograptus flemingii (SALTER), Monoclimacis meneghinii (Gortani), Mediograptus antennularius (Meneghini), Pristiograptus ?dubius dubius (SuEss), Paraplectograptus sp., the trilobite Miraspis mira (BARRANDE), and other taxa allow us to assign this unit to the internationally recognised belophorus Biozone (Štorch 1994, Loydell 2012) of the middle Sheinwoodian Stage of the Wenlock Series (Textfig. 2). This fauna, which includes diverse trilobites and brachiopods, has been assigned to the Miraspis trilobite Assemblage by Chlupáč (1987) or the Miraspis-Mezounia benthic community by Havlíček and Štorch (1990). This bottom-dwelling fauna inhabited a quiet, well-oxygenated environment in a photic zone below storm-wave base. Layer 4 (Text-fig. 1c), where the cooksonioids were found, consists of fine-grained laminated calcareous and tuffaceous shales; layer 5 comprises tuffaceous shales with limestone intercalations. All sediments in this profile (Text-fig. 1c) originated in a moderately shallow, quiet-water environment surrounding a volcanic island the source of our plant specimens. The central part of the island was estimated as about 2 km from the studied outcrop (Horný 1962, Kř́řz 1991, 1992, Chlupáč et al. 1998). The distribution of tuffaceous and calcareous components in these sediments was governed by the intensity of volcanic activity (Chlupáč et al. 1998) and the distance from the volcanic centre; particles of various densities precipitated out in the water column at different distances from volcanic vents (Text-fig. 1b).

Plant fossils were studied and documented using an Olympus SZX-12 binocular microscope equipped with a DP72 digital camera. Specimens were photographed immersed in alcohol under diffuse polarised light using a Canon EOS 50D digital camera equipped with a Sigma Macro 50 lens and circular polarizer filter. The reconstruction of Cooksonia barrandei was done by Jiř́ Svoboda.

Dispersed and in situ spores were macerated using hydrochloric acid (24 hours), hydrofluoric acid (5 days), hydrochloric acid (15 minutes), potassium hydroxide (15 minutes) and washed by water several times. Palynological slides were prepared using a glycerine jelly mounting medium. Plant microfossils were studied and documented using a NIKON BX51 light microscope.

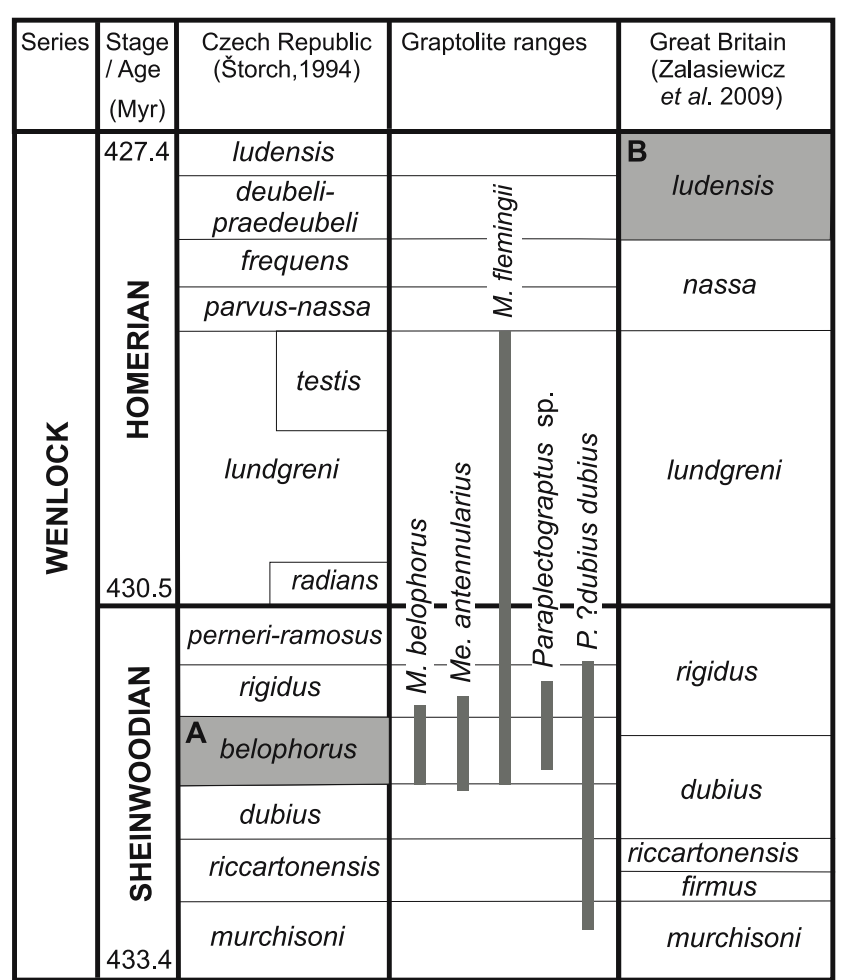

Text-fig. 2. Stratigraphical positions of the earliest records of Cooksonia within graptolite zones of Barrandian (A) and Ireland (B).

Preparation of cuticles was extremely difficult and none of them provided details informative enough to be published. The preparations were studied using an Olympus BX 50 microscope. Plants were also observed in low-vacuum mode of the Hitachi S-3700N SEM, but cellular details (e.g. conducting tissues) were not observed.

All the studied material is housed in the collections of the National Museum, Prague (NM).

\section{Systematic palaeobotany}

\author{
Cooksonia barrandei LIBERTín, J.KvaČEK, BEK, \\ ŽÁRSKÝ et ŠTORCH \\ Text-fig. 3a, b
}

H o l o t y p e. NM-D 552a, b, National Museum, Prague (Text-fig. 3a).

Ty p e 1 o c a 1 i t y. Loděnice, Špičatý vrch-Barrandovy Jámy.

Text-fig. 1. a. Map of the Czech Republic indicating location of the Prague Basin (Barrandian); b. Macrofacies distribution of the Wenlock palaeogeoraphy in Barrandian with indication of the Špičatý vrch locality position (modified after Horný 1962 and Chlupáč et al. 1998); c. Road-cut section Špičatý vrch - Barrandovy Jámy near Loděnice. 1 - laminated tuffaceous shales with limestone intercalations; 2 - alkaline basalt lava; 3 - tuffites and tuffaceous shales; 4 - basal part of the layer (0.5-1 m), laminated calcareous and tuffaceous shales with limestone intercalations (Monograptus belophorus Biozone) - the place where sterile Cooksonia remains were found (first occurrence of index graptolite Monograptus belophorus co-occurring with trilobite Miraspis mira); 5-medial and upper parts of the layer where laminated calcareous and tuffaceous shales gradually pass into platy limestones with interbedded tuffaceous shales (Monograptus belophorus Biozone) containing beside the graptolites diversified trilobite and brachiopod fauna; 6 - platy limestones of Cyrtograptus rigidus Biozone with highly diverse trilobite and brachiopod fauna (Miraspis mira, Cheirurus insignis, Trochurus speciosus, Diacalymene diademata, Niorhynx niobe, Cyrtia maior maior etc). 

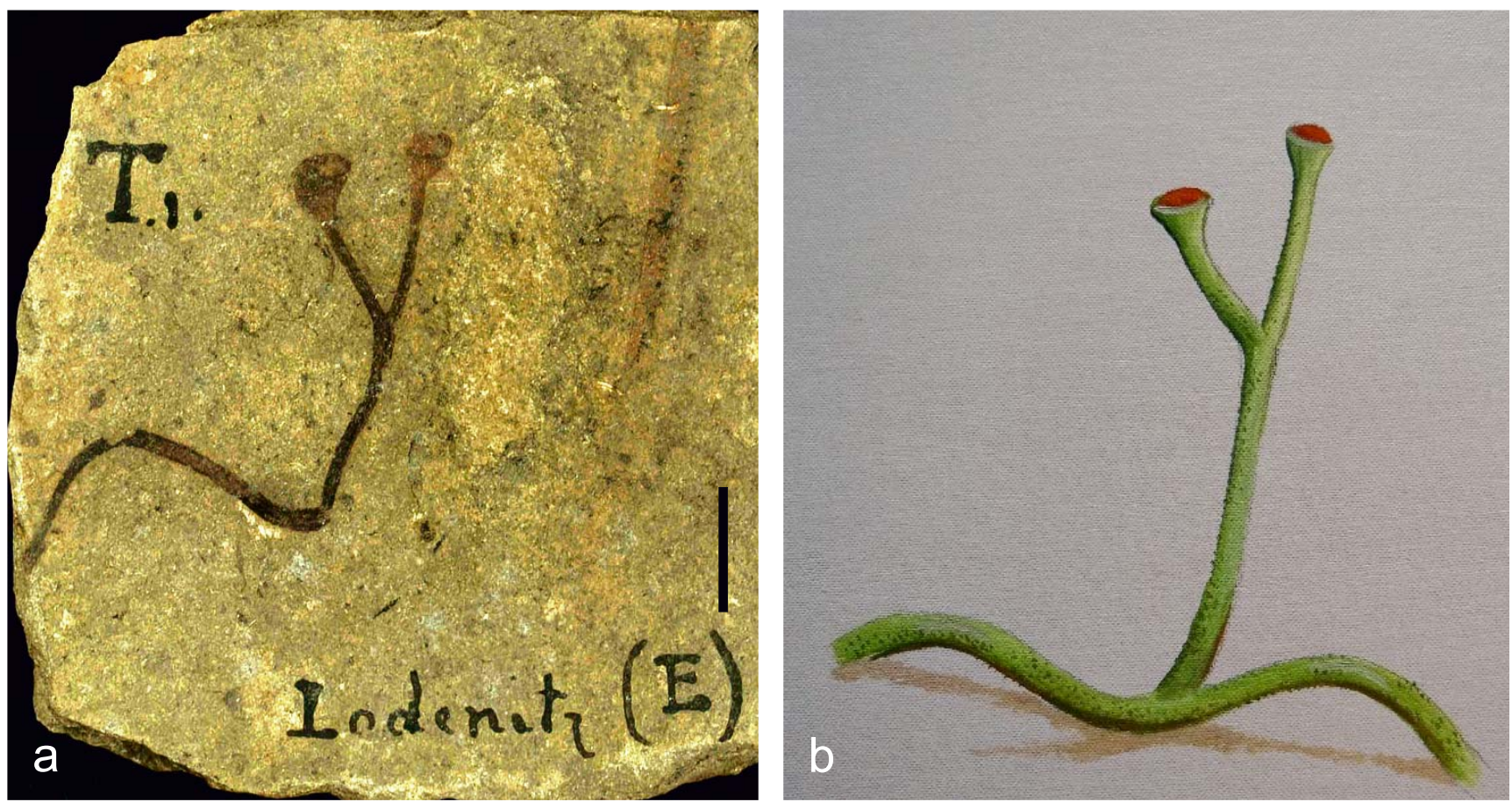

Text-fig. 3. Cooksonia barrandei LiBErTín et al., Loděnice, Špičatý vrch - Barrandovy Jámy, coll. National Museum, Prague, the Czech Republic. a. Holotype, isotomously branched axis with sporangia, NM-D 552a (scale bar $10 \mathrm{~mm}$ ); b. Reconstruction by Jiří Svoboda.

Type horizon. Monograptus belophorus Biozone, Motol Formation, middle Sheinwoodian, Wenlock, Silurian.

R e marks. For diagnosis, description, and spores in situ see Libertín et al. (2018). However, some details, particularly related to the handwritten notes, were not mentioned in the paper referred to above. Both part and counterpart of the holotype bear the name of the locality handwritten in black ink directly on the rock by Joachim Barrande. The handwritten note is as follows: Lodenitz (E). The letter E indicates Barrande's labeling of the Silurian section as depicted in his diary (Text-fig. 4). This letter on the type specimen, together with associated zonal index graptolite Monograptus belophorus (MENEGHINI), helped the authors to identify the source horizon of the type material.
Additionally, we present here an idealized reconstruction of $C$. barrandei showing an overtopped terminal part of the axis and curved, probably creeping main axis. This reconstruction was prepared in collaboration with an artist Jiří Svoboda (Text-fig. 3b).

\section{Cooksonia sp.}

Text-fig. 5a-c

L o c a $l$ i t y . Loděnice, Špičatý vrch - Barrandovy Jámy.

H o ri z on. Monograptus belophorus Biozone, Motol Formation, middle Sheinwoodian, Wenlock, Silurian.

M a t e r i a 1 . Specimens, NM-D 550, NM-D 554, NM-D 557a, b, National Museum, Prague.

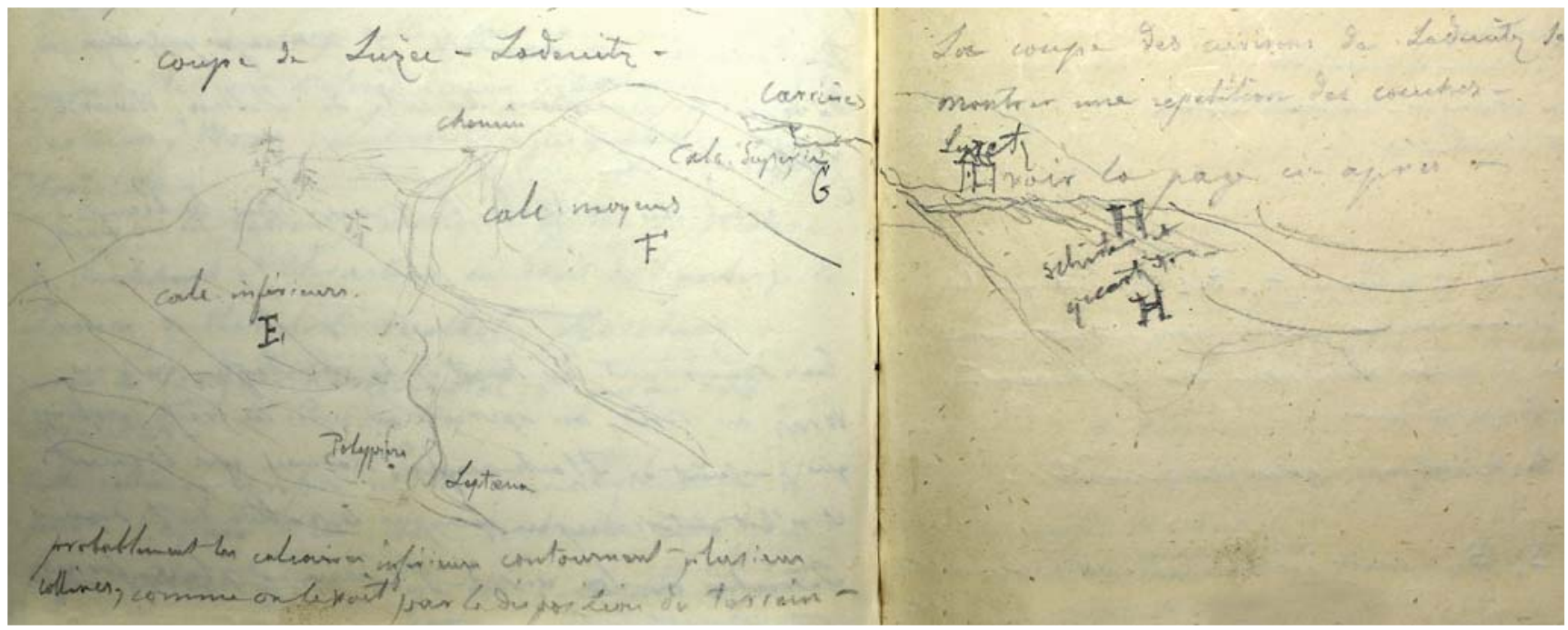

Text-fig. 4. Pages from handwritten diary of Joachim Barrande from years 1841 - 1846 (coll. National Museum, Prague, the Czech Republic). 
Description. The largest specimen (NM-D 554) is $75 \mathrm{~mm}$ long and $3.2 \mathrm{~mm}$ broad in its basal part (Text-fig. $5 a)$. Its axes are three times isotomously branched. In the lower proximal branches, one branch subsequently becomes dominant. This means that the branches are isotomous with overtopping. They do not form a pseudomonopodium, because branches of higher orders are uniform. Branching is comparatively regular; segments branch off at acute angles of $30^{\circ}$ to $40^{\circ}$, and range from $7 \mathrm{~mm}$ to $25 \mathrm{~mm}$ in length (Text-fig. $5 \mathrm{a})$. The sporangium ( $3 \mathrm{~mm}$ in diameter) is loosely attached (attachment being visible only in polarized light Text-fig. 5a).

There are two further specimens (NM-D 550, NM-D 557a, b; Text-fig. 5b, c) showing putative terminally-borne sporangia (3-3.8 $\mathrm{mm}$ in diameter). The specimens are branched isotomously three times, with overtopping. The precise mode of attachment of sporangia is obscured by the sporangia themselves covering critical areas. Specimen NM-D 550 shows a $25 \mathrm{~mm}$ long terminal axis. Sporangia are well-preserved in its left part. Specimen NM-D 557a and its counterpart NM-D $557 \mathrm{~b}$ show several putative sporangia forming one group, loosely attached and of moderate preservation. The axis has the same general form as NM-D550 and NM-D554.

Discussion. The above described fossil plant material identified as Cooksonia sp. differs from Cooksonia barrandei (Libertín et al. 2018) in having upright axes and slender terminal parts of subtending axes and sporangia without a rim. Additionally, terminal parts of Cooksonia sp. branches are shorter than C. barrandei, and their branching is more frequent.

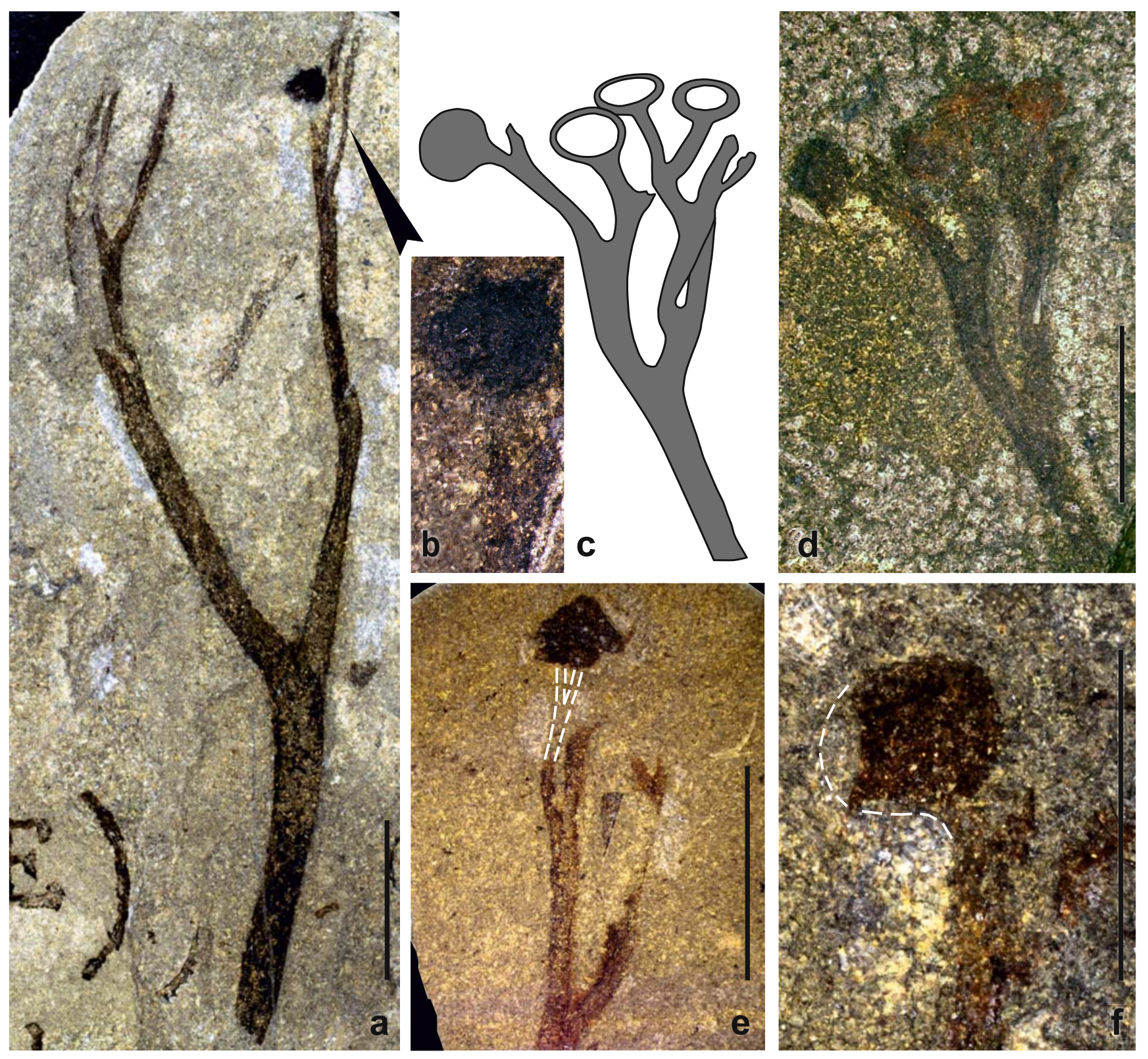

Text-fig. 5. Cooksonia sp., Loděnice, Špičatý vrch - Barrandovy Jámy, coll. National Museum, Prague, the Czech Republic. a. Three times isotomously branched axis with one preserved sporangium, NM-D 554 (scale bar $10 \mathrm{~mm}$ ); b. Terminal part of three times isotomously branched axis with loosely attached sporangia, detail of Text-fig. 5a; c. Schematic drawing of terminal part of axis bearing several sporangia, NM-D 550; d. Terminal part of axis bearing several sporangia, NM-D 550 (scale bar $10 \mathrm{~mm}$ ); e. Terminal part of branch with loosely attached putative sporangia forming one group, NM-D 557a (scale bar $10 \mathrm{~mm}$ ); f. Fragmentary sporangium, detail of Text-fig. $5 \mathrm{~d}$ (scale bar $10 \mathrm{~mm}$ ). 
The specimens described by Libertín et al. (2002) resemble Cooksonia sp. rather than C. barrandei in the absence of an apparently procumbent basal part of its axis and having terminal axes only slightly widened without any pronounced sporangial rim. C. bohemica differs from Cooksonia sp. in having a wider branching angle, short subtending axes and kidney-shaped sporangia (Schweitzer 1980).

Cooksonia sp. also resembles Concavatheca banksii from the Lochkovian of England (Habgood et al. 2002, Morris et al. 2012) in having similarly shaped terminal axes subtending sporangia. According to Morris et al. (2012), Concavatheca differs from Cooksonia in having, "extension of the sporangial cavity into the distally widening subtending axis as exemplified by changes in the shape of the epidermal cells". This character is not possible to distinguish in our material, although the shapes of subtending axes of both Concavatheca banksii and Cooksonia sp. are similar. The holotype of Concavatheca banksii is a charcoalified mesofossil, while our material consists of compressions. Due to different preservation states of the two species, direct and detailed comparisons cannot be made. However, there are more distinguishing characters between the above mentioned taxa, particularly in sizes of their axes and sporangia. Three subspecies of Cooksonia pertoni [C. pertoni ssp. pertoni, C. pertoni ssp. synorispora from Pridoli (Fanning et al. 1988) and C. pertoni ssp. reticulispora from Lochkovian (Habgood et al. 2002)] described from Great Britain differ from Cooksonia sp. particularly in their smaller size. Cooksonia hemisphaerica from the Lochkovian of England (Lang 1937), recorded also from the Pridoli Series of the Barrandian area (Obrhel 1962), differs from Cooksonia sp. in both its size and in the shape of the sporangia, which are hemispherical. Cooksonia sp. differs from Cooksonia crassiparietilis from the Early Devonian of Kazakhstan (Yurina 1969) in having a wider branching angle $\left(60^{\circ}\right)$ and more elliptically shaped sporangia. Cooksonia sp. from the uppermost Homerian of Tipperary in Ireland (Edwards et al. 1983) differs from our material in size; their axes are only about $0.2 \mathrm{~mm}$ in diameter and having slightly widened axes subtending sporangia (Morris et al. 2012).

The dispersed spore assemblage prepared from the same sediment samples bearing Cooksonia fossils provided at least five other trilete spore types, suggesting further diversity of cooksonioid and similar plants. The dispersed spores will be described in a separate paper.

The Cooksonia fossils described here come from what was then the southern hemisphere, where the peri-Gondwana terranes and microcontinents, including those of the present Bohemian Massif, were situated at mid latitude (Cocks and Torsvik 2006). The rocks containing these fossils are products of near-shore marine sedimentation associated with volcanic islands, the largest of which formed today's Svatý Jan Volcanic Centre (Havlíček and Štorch 1990, Kř́iž 1991).

\section{Conclusions}

Material documented here records the extent of the currently known plant diversity associated with Cooksonia barrandei during the middle Sheinwoodian Stage (ca. 432 Myr) of the Silurian Period. Megafossils are attributable to Cooksonia sp., and five taxa of dispersed spores derived from at least five different plants. Additionally, the first reconstruction of Cooksonia barrandei is presented to the broader public. These fossils support the existence of a relatively diverse terrestrial flora in the volcanic archipelago of the Barrandian area, which at this time was situated on the northern margin of the supercontinent of Gondwana.

\section{Acknowledgements}

We are grateful to all three reviewers Dianne Edwards (Cardiff University), Paul Kenrick (Natural History Museum, London), Charles Wellman (The University of Sheffield), for their critical comments and suggestions. Financial support from the Grant Agency of Czech Republic, First vascular land plants and palynomorphs from the Silurian-Lower Devonian of the Barrandian area, Czech Republic (GAČR 17-102333S) is acknowledged. Part of this contribution was also supported by the Research Program of the Institute of Geology CAS, v.v.i. (RVO67985831).

\section{References}

Boyce, C. K. (2008): How green was Cooksonia? The importance of size in understanding the early evolution of physiology in the vascular plant lineage. - Paleobiology, 34: 179-194.

https://doi.org/10.1666/0094-8373(2008)034[0179:HGWCTI]2.0.CO;2

Chlupáč, I. (1987): Ecostratigraphy of Silurian trilobite assemblages of the Barrandian area. - Newsletters on Stratigraphy, 17: 169-186. https://doi.org/10.1127/nos/17/1987/169

Chlupáč, I., Havlíček, V., Kukal, Z., Kříž, J., Štorch, P. (1998): Palaeozoic of the Barrandian (Cambrian to Devonian). - Czech Geological Survey, Prague, 183 pp.

Cocks, L. R. M., Torsvik, T. H. (2006): European geography in a global context from the Vendian to the end of Palaeozoic. - In: Gee, D. G., Stephenson, R. A. (eds), European Lithosphere Dynamics. Memoirs, Geological Society, London, 32: 83-95. https://doi.org/10.1144/GSL.MEM.2006.032.01.05

Edwards, D., Feehan, J., Smith, D. G. (1983): A late Wenlock flora from Co. Tipperary, Ireland. - Botanical Journal of the Linnean Society, 86: 19-36. https://doi.org/10.1111/j.1095-8339.1983.tb00715.x

Fanning, U., Richardson, J. B., Edwards, D. (1988): Cryptic evolution in an early land plants. - Evolutionary Trends in Plants, 2(1): 13-24.

Edwards, D., Wellman, C. H. (2001): Embryophytes on land: the Ordovician to Lochkovian (Lower Devonian) record. - In: Gensel, P. D., Edwards, D. (eds), Plants Invade the Land. Evolutionary and Environmental Perspectives. Columbia University Press, New York, pp. 3-28. https://doi.org/10.7312/gens11160-003

Habgood, K. S., Edwards, D., Axe, L. (2002): New perspective of Cooksonia from the Lower Devonian of the Welsh Borderland. - Botanical Journal of the Linnean Society, 139: 339-359.

https://doi.org/10.1046/j.1095-8339.2002.00073.x 
Havlíček, V., Štorch, P. (1990): Silurian brachiopods and benthic communities in the Prague Basin (Czechoslovakia). - Rozpravy ÚÚG, 48: 1-275.

Horný, R. (1962): Das mittelböhmische Silur. - Geologie, 11: 843-916.

Kraft, P., Kvaček, Z. (2017): Where the lycophytes come from? - A piece of the story from the Silurian of peri-Gondwana. - Gondwana Research, 45: 180-190. https://doi.org/10.1016/j.gr.2017.02.001

Kraft, P., Pšenička, J., Sakala, J., Frýda, J. (2018): Initial plant diversification and dispersal event in upper Silurian of the Prague Basin. - Palaeogeography, Palaeoclimatology, Palaeoecology, 514: 144-155.

https://doi.org/10.1016/j.palaeo.2018.09.034

Kříž, J. (1991): The Silurian of the Prague Basin (Bohemia) - tectonic, eustatic and volcanic controls on Facies and Faunal development. - Special Papers in Palaeontology, 44: 179-203.

Kř́žz, J. (1992): Silurian field excursions: Prague Basin (Barrandian), Bohemia. - Geological series, National Museum of Wales, 13: 1-111.

Lang, W. H. (1937): On the plant-remains from the Downtonian of England and Wales. - Philosophical Transactions of the Royal Society, B: Biological Sciences, 227: 245-291. https://doi.org/10.1098/rstb.1937.0004

Libertín, M., Kvaček, J., Bek, J., Žárský, V., Štorch, P. (2018): Sporophytes of polysporangiate land plants from the early Silurian period may have been photosynthetically autonomous. - Nature Plants, 4: 269-271. https://doi.org/10.1038/s41477-018-0140-y

Libertín, M., Labut'a, R., Dašková, J. (2002): Nález nejstarších cévnatých rostlin v Českém masivu [The oldest vascular plants from the Bohemian Massif]. - Zprávy o geologických výzkumech v roce 2002: 127. (in Czech)
Loydell, D. K. (2012): Graptolite biozone correlation charts. - Geological Magazine, 149: 124-132. https://doi.org/10.1017/S0016756811000513

Morris, J. L., Edwards, D., Richardson, J. B., Axe, L., Davies, K. L. (2012): Further insights into trilete spore producers from the Early Devonian (Lochkovian) of the Welsh Borderland, U.K. - Review of Palaeobotany and Palynology, 185: 35-36. https://doi.org/10.1016/j.revpalbo.2012.08.001

Obrhel, J. (1962): Die Flora der Přídolí-Schichten (Budňany-Stufe) des mittelböhmischen Silurs. - Geologie, 11: 83-97.

Schweitzer, H. J. (1980): Die Gattungen Renalia Gensel und Psilophyton Dawson im Unterdevon des Rheinlandes. - Bonner paläobotanische Mitteilungen, 6: 1-34.

Storch, P. (1994): Graptolite biostratigraphy of the Lower Silurian (Llandovery and Wenlock) of Bohemia. - Geological Journal, 29: 137-165. https://doi.org/10.1002/gj.3350290204

Taylor, T. N., Taylor, E. L., Krings, M. (2009): Palaeobotany. The biology and evolution of fossil plants (2nd edition). - Elsevier (Academic Press), Amsterdam, 1230 pp.

Yurina, A. L. (1969): Devonskaya flora Tsentral'nogo Kazakhstana [The Devonian flora of Central Kazakhstan] (Materialy po geologii Tsentral'nogo Kazakhstana, vol. 8). - Izdatel'stvo Moskovskogo Universiteta, Moskva, 207 pp. (in Russian)

Zalasiewicz, J. A., Taylor, L., Rushton, W. A., Loydell, D. K., Rickards, R. B., Williams, M. (2009): Graptolites in British stratigraphy. - Geological Magazine, 146: 785-850.

https://doi.org/10.1017/S0016756809990434 